\title{
Physiologic Testing
}

National Cancer Institute

\section{Source}

National Cancer Institute. Physiologic Testing. NCI Thesaurus. Code C63481.

The examination of variables concerning organism or bodily functions. 